\title{
Atmospheric deposition coupled terrestrial export of organic carbon in Ganga River (India): linking cross-domain carbon transfer to river DOC
}

\author{
Jitendra Pandey $\cdot$ Anand V. Singh $\cdot$ Rachna Singh $\cdot$ Pooja Kaushik $•$ \\ Usha Pandey
}

Received: 2 February 2015/Accepted: 17 August 2015/Published online: 27 August 2015

(C) The Author(s) 2015. This article is published with open access at Springerlink.com

\begin{abstract}
The atmosphere-land-water connectivity of dissolved organic carbon (DOC) is not altogether accounted in major rivers of India despite recent researches highlighting its importance. We studied the coupled effect of atmospheric deposition (AD) and local land use on DOC buildup in Ganga River for a period of 6 years. The AD-OC input increased consistently over time and there was over 1.5- to 1.8-fold increase in 2012 relative to 2007. Microbial activity and water soluble organic carbon (WSOC) in sub-catchment and DOC in land surface runoff increased consistently over time along the gradient of AD input. The river DOC showed positive correlation $\left(R^{2}=0.24-0.84 ; p<0.001\right)$ with AD-OC and runoff DOC and WSOC showed positive correlation $\left(R^{2}=0.96 ; p<0.001\right)$ with soil microbial activity. Principal component analysis segregated study sites into four groups demarcating source relationships. Our study, that forms the first report on atmosphere-land-water transfer of organic carbon in Ganga River, suggests that future climate models should include region-specific time series data on changing state of atmosphere- land-water connectivity and associated shift in carbon balance of major rivers for more accurately predicting the climate change drivers.
\end{abstract}

Keywords Atmospheric deposition - Climate change drivers - Dissolved organic carbon - Ganga River . Land use $\cdot$ Surface runoff

\section{Introduction}

The human alteration of carbon cycle is a key node of perturbed Earth System functions such as climate change, global transport of pollutants, changing biogeochemical cycles, ecosystem productivity and plant species shift (Reich et al. 2006; Ramanathan and Garmichael 2008; Jurado et al. 2008; Langley and Megonigal 2010; Pandey 2011; Pandey et al. 2014a). Despite the fact that atmosphere-land-water connectivity is central to global $\mathrm{C}$ cycling, most of the prediction models did not explicitly consider atmosphere-land-water linkages in regional and global $\mathrm{C}$ budgets. Surface water especially rivers respond differently than uplands to environmental perturbations and have relevance in constructing a complete regional $\mathrm{C}$ budget (Cole et al. 2007; Buffam et al. 2011). Biogeochemical cycling of carbon (C) across the terrestrial-aquatic interface is

J. Pandey $(\varangle) \cdot$ A. V. Singh $\cdot$ R. Singh $\cdot$ P. Kaushik

Ganga River Ecology Research Laboratory, Environmental Science Division, Centre of Advanced Study in Botany,

Banaras Hindu University, Varanasi 221005, India

e-mail: jiten_pandey@rediffmail.com

U. Pandey

Department of Botany, Faculty of Science and Technology, Mahatma Gandhi Kashi Vidyapith University, Varanasi 221002 , India 
dynamically linked with the water cycle. Not only is the movement of $\mathrm{C}$ controlled in a major way by the movement of water, but also the processes of transformations between organic and inorganic forms are strongly influenced by the movement of water.

The knowledge of regional sensitivity of landscapes, whether as $\mathrm{C}$ sink or source, the magnitude of $\mathrm{C}$ storage or flux and vulnerability to anthropogenic perturbations are all important for understanding regional $\mathrm{C}$ budget. Because freshwater covers a small fraction of the Earth's surface area, inland freshwater ecosystems have rarely been considered as potentially important component of regional or global scale $\mathrm{C}$ budget (Cole et al. 2007). Under the rising anthropogenic pressure, data on changing state of atmosphere-land-water connectivity coupled with climatic heterogeneity provide valuable information on which the possible linkages of climate change drivers can be keyed. Further, although the oxidized form of carbon $\left(\mathrm{CO}_{2}\right)$ has received major scientific attention globally, regional and global scale data on atmosphere-land-water linkages of reduced carbon, especially in the form of organic carbon, are very scarce (Buffam et al. 2011). In India, the National Carbon Project (NCP), which aims at improving, understanding and quantification of net $\mathrm{C}$ balance, has been implemented with three major domains namely, vegetation $\mathrm{C}$ pool, soil $\mathrm{C}$ pool and vegetationatmospheric fluxes (Dadhwal 2012). This mega project did not, however, consider C pool of surface waters. To date, no data so far are available from India addressing explicitly the human-induced changes in atmosphere-land-water C transfer and associated shift in C balance in major rivers of the country. The newly established Ministry of Water Resources, River Development and Ganga Rejuvenation by the Government of India may warrant watershed-scale research initiatives to understand how the transfer of terrestrial $\mathrm{C}$ to river ecosystems is being influenced by land use change and AD inputs.

Atmospheric deposition of OC in catchment may alter the quality and quantity of soil organic matter and consequently the quality of runoff emerging from these land surfaces. The responses of catchment $\mathrm{C}$ pool to AD-OC, however, may vary depending on catchment properties including land use change and soil nutrient status (Aber et al. 1998; Kopácèk et al. 2013). The coupled effect of terrestrial C and AD-OC may influence the storage and flux of $\mathrm{C}$ in receiving water bodies. Therefore, long-term time series data integrating crossdomain processes are important for predicting specific climate change drivers and designing action plans for integrated river basin management (IRBM). The available literature suggests that the atmospheric deposition contributes significantly to land OC pool. Willey et al. (2000) reviewed the measurement of dissolved organic carbon (DOC) in rain water and estimated that of the total global AD-OC input of $400,310 \mathrm{Tg} \mathrm{C} \mathrm{yr}^{-1}$ corresponds to land input. Therefore, for understanding and quantification of net regional $\mathrm{C}$ balance, data on $\mathrm{AD}-\mathrm{OC}$ and associated shift in land-water transfer to major rivers are important. However, there is a general dearth of studies addressing explicitly the human-induced changes in atmosphere-land-water transfer of organic carbon and associated shift in $\mathrm{C}$ balance in major rivers of India. This study presents data on atmospheric deposition of OC; effect of AD-OC and land use on land surface runoff DOC; and the coupled effect of $\mathrm{AD}-\mathrm{OC}$ and land derived DOC on the concentration of DOC in Ganga River. We hypothesized that, together with atmospheric- OC, the land derived DOC in surface runoff enhances the DOC concentration in Ganga River. To test this hypothesis, we evaluated, if the pattern of microbial activity in sub-catchment, terrestrial $\mathrm{C}$ flushing through runoff and DOC in the river varied over time along the gradient of AD-OC.

\section{Materials and methods}

Study area

The data presented here are the results of six consecutive years (March 2007 to February 2013) of study conducted at seven sites along a $35 \mathrm{~km}$ long stretch of Ganga River at Varanasi $\left(25^{\circ} 18^{\prime} \mathrm{N}\right.$ lat. and $83^{\circ} 1^{\prime} \mathrm{E}$ long.) (Figure 1). The Ganga River together with Brahmaputra-Meghna river system is second only to Amazon with total drainage area of 1.75 million $\mathrm{km}^{2}$. The Indo-Gangetic Plains, which constitute the most fertile agricultural belt in India, represent the highest population density in the country. During the last two decades the region witnessed unprecedented growth of urban-industrial sectors. As a result, the Ganges basin, along its $2525 \mathrm{~km}$ course from Gangotri in Himalaya to its confluence with Bay of Bengal, receives massive input of air-borne carbon and other pollutants. Each site presented in Fig. 1 represents three sub-sites considered separately for collecting atmospheric deposition samples (5-20 m distance from the river bank), 
surface runoff (at discharge outlet adjacent to river; 5-20 m distance from the river bank) and mid-stream river water samples (considered in the mid-stream centrally to the mean width of the respective site). Site selection was based on local land uses and the nature of emission sources (Table 1). Site 1 is relatively in a natural state and all other sites were invariably human disturbed. Land use at Site 2 constitutes agriculture with natural patches; Site 3 predominantly agricultural; Site 4 anthropogenic dredging; Site 5 and 6 urban and at Site 7 it is characterized by urban with mosaic of woodland. Samples were collected for six consecutive years and for data presentation the times series was divided as: Year 2007, (March 2007 to February 2008); 2008,

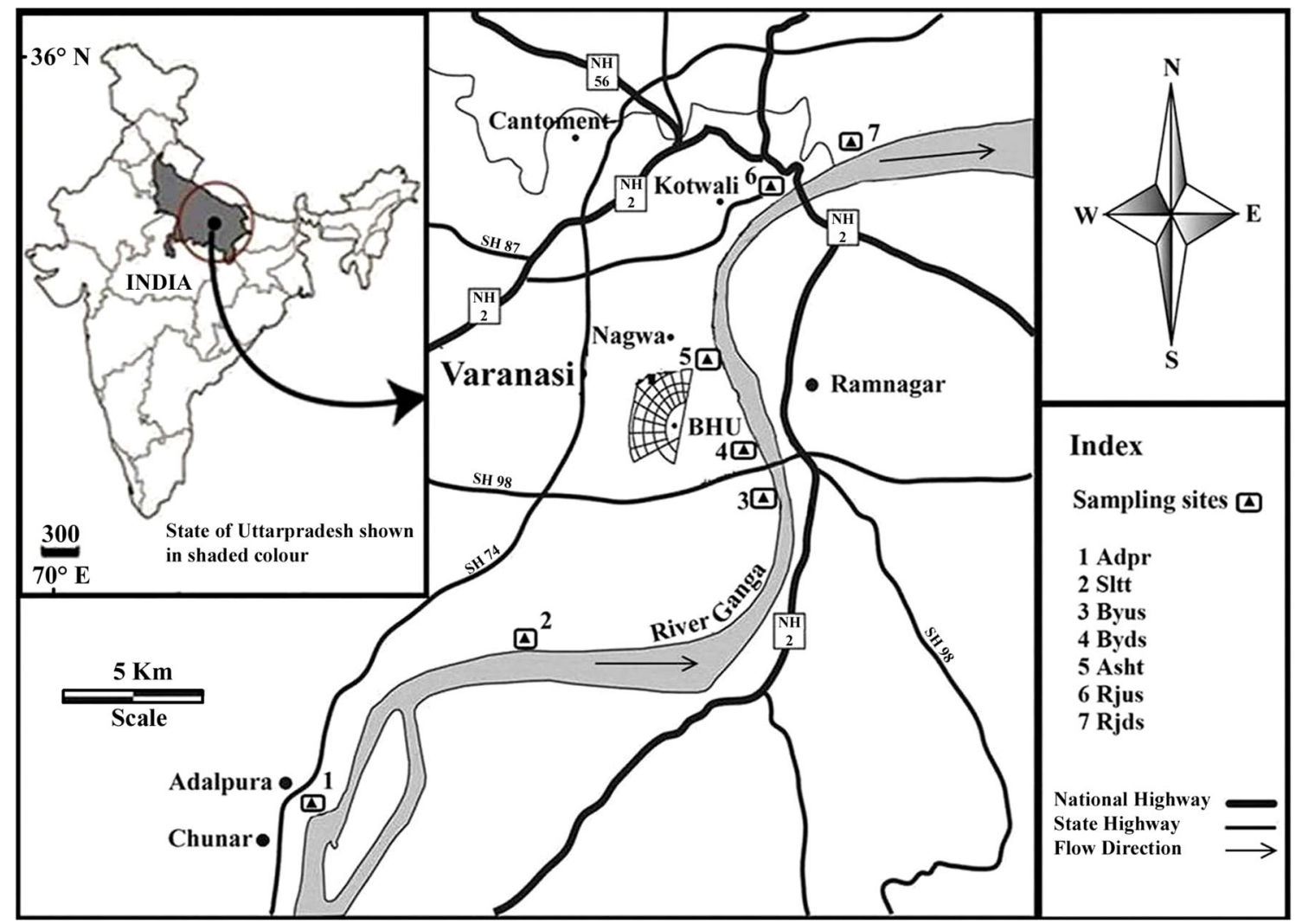

Fig. 1 Location of the study sites at Ganga River. 1 Adalpura (Adpr); 2 Shultankeshwar ghat (Sltt); 3 Bypass upstream (Byus); 4 Bypass downstream (Byds); 5 Assi ghat (Asht); 6 Rajghat upstream (Rjus); 7 Rajghat downstream (Rjds)

Table 1 Description of major emission source, river attributes and sub-catchment characteristics at seven study sites

\begin{tabular}{|c|c|c|c|c|c|c|c|}
\hline No. & Name & Code & $\begin{array}{l}\text { Mean } \\
\text { Depth } \\
\quad(\mathrm{m})\end{array}$ & $\begin{array}{l}\text { Average velocity } \\
\left(\mathrm{ms}^{-1}\right)\end{array}$ & Emission source & $\begin{array}{l}\text { Area } \\
\left(\mathrm{km}^{2}\right)\end{array}$ & Land use \\
\hline 1. & Adalpura & Adpr & 21 & $0.40 \pm 0.02$ & $\begin{array}{l}\text { Long-range } \\
\text { transport }\end{array}$ & 84 & Natural patches \\
\hline 2. & $\begin{array}{l}\text { Shultankeshwar } \\
\text { Ghat }\end{array}$ & Sltt & 21 & $0.40 \pm 0.03$ & $\begin{array}{l}\text { Long-range } \\
\text { transport }\end{array}$ & 114 & $\begin{array}{l}\text { Agriculture with natural } \\
\text { patches }\end{array}$ \\
\hline 3. & Bypass upstream & Byus & 12 & $0.39 \pm 0.02$ & Havy duty vehicle & 540 & Rural and agricultural \\
\hline 4. & $\begin{array}{l}\text { Bypass } \\
\text { downstream }\end{array}$ & Byds & 12 & $0.39 \pm 0.01$ & Havy duty vehicle & 62 & Anthropogenic dredging \\
\hline 5. & Assi Ghat & Asht & 14 & $0.26 \pm 0.01$ & Urban emission & 72 & Residential, urban \\
\hline 6. & Rajghat upstream & Rjus & 20 & $0.36 \pm 0.02$ & $\begin{array}{l}\text { Urban; biomass } \\
\text { burning }\end{array}$ & 85 & Urban \\
\hline 7. & $\begin{array}{l}\text { Rajghat } \\
\text { downstream }\end{array}$ & Rjds & 18 & $0.32 \pm 0.01$ & Urban emission & 90 & Urban; woodland \\
\hline
\end{tabular}


(March 2008 to February 2009); 2009, (March 2009 to February 2010); 2010, (March 2010 to February 2011); 2011, (March 2011 to February 2012); and 2012, (March 2012 to February 2013).

The climate is tropical monsoonal, marked by a hot and dry summer, a humid rainy season and a cold winter season. During summer, day temperature varied between 29 and $46.2{ }^{\circ} \mathrm{C}$. During winter, night temperature at rare occasion drops below freezing. Mean annual rainfall varied between 870 and $1130 \mathrm{~mm}$, relative humidity between 27 and $83 \%$ (summer) and 58 and $99 \%$ (rainy season). About $90 \%$ of the total annual rainfall is received in rainy season. Wind direction shifts from predominantly westerly and southwesterly in October through April to easterly and north-westerly in remaining months. The soil is alluvial fluvisol associated with recurrent floods or long wetness, recent sedimentation and high natural fertility. Daily climate data consisting of precipitation, temperature, wind and humidity were taken from Meteorological Unit, Department of Geophysics, Banaras Hindu University.

Measurements

\section{Atmospheric deposition}

Atmospheric deposition samples were collected at monthly intervals following an identical protocol. Samples were collected using bulk samplers made up of 5L high density polyethylene bottle connected to a Teflon funnel (diameter: $15 \mathrm{~cm}$ ) with PVC needles devised on the top to avoid bird nesting. Samplers were placed at 5-20 m distance from the river bank and maintained at a height of $2 \mathrm{~m}$ to avoid collection of re-suspended matters. In order to prevent large changes in the concentrations, thymol was used as a biocide in the collection buckets (Gillet and Ayers 1991). At the end of the sampling period the funnel was rinsed with double distilled water to collect deposits from the funnel walls. A $50 \mathrm{ml}$ of sub-sample of atmospheric deposit collected in the bottle and a $50 \mathrm{ml}$ sub-sample of the rinsing water was filtered using pre-combusted Whatman glass fiber filter $(0.7 \mu \mathrm{m})$ and the organic carbon was analyzed following $\mathrm{KMnO}_{4}$ digestion procedure (Michel 1984). The samples were screened for contamination using high soluble reactive $\mathrm{P}(>0.2 \mathrm{mg})$ as an indicator (Lohse et al. 2008).

\section{Catchment soil}

Microbial activity in catchment soil was measured in terms of substrate-induced respiration (SIR). For this purpose, soil samples (0-10 cm depth) were collected monthly from three randomly selected blocks (plot size, $20 \times 20 \mathrm{~m}$ ) from each study site. Soil sampling blocks were selected in riparian zone of the respective sites at a distance of 50-100 $\mathrm{m}$ from the river bank. Microbial activity was measured by amending $20 \mathrm{~g}$ of soil sample (moisture content adjusted to $55 \%$ ) with $120 \mathrm{mg}$ of glucose at the beginning of incubation (Anderson and Domsch 1978). The $\mathrm{CO}_{2}$ produced was trapped in $0.5 \mathrm{~N} \mathrm{NaOH}$ and determined by titrating excess of $\mathrm{NaOH}$ with $0.5 \mathrm{~N} \mathrm{HCl}$. Water soluble organic carbon (WSOC) in aqueous extract of soil was determined following dichromate oxidation titration (Ciavatta et al. 1991).

\section{Water chemistry}

We collected mixed surface runoff samples to represent a wash-out effect characteristic of different site functions. For this purpose, sites were selected considering different land uses such as residential, agricultural, roads, anthropogenic dredging, woodland etc. and runoff samples were collected at a discharge outlet adjacent to the river (5-20 m distance from the river bank). There was only one exit to discharge the runoff from each area marked for the purpose. The strategy was to collect surface runoff to represent characteristics of this mixed area. Three such outlets, armed with artificial barriers, were installed in each sub-catchments. The flow velocity was measured using a flow meter and the runoff was determined considering flow velocity and cross area of the discharge outlet. The samples were collected manually during rain event using pre-sterilized sampling bottles. The sampling was initiated with first flush, and based on the duration of surface runoff, the sampling interval was kept 10-30 min. River water samples were collected in replicates from mid-stream of the river monthly from each site, directly below the surface $(15-25 \mathrm{~cm}$ depth), in acid-rinsed $5 \mathrm{~L}$ plastic containers. 
The $\mathrm{NO}_{3}{ }^{-}-\mathrm{N}$ in water samples was estimated using brucine sulphanilic acid method (Voghel 1971), ammonia-N using Nessler's reagent method (Maiti 2001) and total dissolved nitrogen (TDN) following high temperature persulphurate digestion. Dissolved organic nitrogen (DON) was computed as TDN minus dissolved inorganic nitrogen (DIN), where DIN represents the sum of $\mathrm{NO}_{3}{ }^{-}-\mathrm{N}$ and $\mathrm{NH}_{4}{ }^{+}-\mathrm{N}$ (Perakis and Hedin 2002). Since most of the $N$ was inorganic, the $C: N$ ratio presented here represents DOC: TDN. Dissolved organic carbon (DOC), the fraction of organic carbon filtered through a $0.7 \mu \mathrm{m}$ pore size filter, in runoff and river water samples was estimated using a $\mathrm{KMnO}_{4}$ digestion procedure (Michel 1984). For this purpose, a known volume of filtered water was mixed with acidified N/80 potassium permanganate and incubated at $37{ }^{\circ} \mathrm{C}$. Organic carbon was estimated by titrating to quantify oxygen after $4 \mathrm{~h}$ of incubation (APHA 1998). As one mole of oxygen (32 g) is released for each mole of C (12 g) fixed, the factor 0.375 was used to convert titration results to organic carbon. For quality assurance, the analytical accuracy of the data generated in the laboratory was validated by repeated calibration using different concentrations of standard potassium hydrogen phthalate solution. Repeated calibration showed $\mathrm{KMnO}_{4}$ oxidation efficiency of $75 \%$ and therefore, an efficiency factor of 1.33 was used to ensure analytical accuracy.

\section{Statistical analysis}

Significant effects of site and time series were tested using analysis of variance (ANOVA). Samples were collected in replicates and all the measurements were considered in ANOVA model. To justify uncertainty of the mean, arithmetic means are accompanied by \pm 1 SE. Coefficient of variation (cv) with least significant difference $(\alpha=0.05)$ across time was computed for expressing data variability. The Mann-Kendall test and Sen's slope estimator (XLSTAT 2013) were used for detecting the trend direction and magnitude of change in seasonal atmospheric deposition data sets. Principal component analysis (PCA) was used to construct the overall spatial and temporal profile of OC for the entire study period. Correlation coefficient $\left(R^{2}\right)$ and regression analyses were used for testing the extent of linearity in relationships. Confidence limits above 95 $(\alpha<0.05)$ were considered as significant. SPSS package (version 16) was used for statistical analysis.

\section{Results}

The atmospheric deposition of organic carbon (AD-OC) increased over time and there was over 1.5- to 1.8fold increase in AD-OC in 2012 relative to 2007 (Fig. 2). At Rjus and Rjds sites, more than $80 \%$ of atmospheric deposits contained OC above $237.5 \mu \mathrm{mol} \mathrm{l}^{-1}$. Organic carbon concentration in rain water followed a trend similar to AD-OC (Fig. 2). Seasonally, deposition of OC was lowest in monsoon and highest in winter (Fig. 3). Mann-Kendall test and Sen's slope showed steep slopes with significant seasonality ( $p<0.001$; Fig. 3). Seasonally, the AD-OC input varied between $3.4 \mathrm{~kg} \mathrm{ha}^{-1}$ season $^{-1}$ (Adpr, rainy season) and $11.9 \mathrm{~kg} \mathrm{ha}^{-1}$ season $^{-1}$ (Rjds, summer season). Month-wise, the AD-OC was highest in December (Byds, Asht, Rjus and Rjds) and January (Adpr, Sltt and Byus) (Fig. 4) although the differences in AD-OC fluxes between these months were not significant. On spatial scale, deposition of OC was found to be the lowest at Adpr site. Spatio-temporal variations in AD-OC were statistically significant ( $p<0.001$; ANOVA).

Microbial activity (measured in terms of substrate-induced respiration, SIR) in top soil of the sub-catchment increased consistently overtime (Fig. 5). The SIR increased consistently along the pollution gradient from Adpr (3.84-5.70 $\left.\mu \mathrm{g} \mathrm{CO}-\mathrm{C} \mathrm{g}^{-1} \mathrm{~h}^{-1}\right)$ to Rjds $\left(6.81-11.74 \mu \mathrm{g} \mathrm{CO}-\mathrm{C} \mathrm{g}^{-1} \mathrm{~h}^{-1}\right)$ and this trend was common throughtout the study period. Water soluble organic carbon (WSOC) showed temporal and spatial trends similar to that of SIR (Fig. 5). The differences in SIR and WSOC with respect to site and year were significant ( $p<0.001$; ANOVA). Concentration of DOC in runoff varied with site and increased consistently over time from 2007 to 2012 (Fig. 2). The increase in runoff DOC over time was highest at Rjds, although the overall flux of DOC was highest at Byus (115-163 kg ha $\left.\mathrm{kear}^{-1}\right)$. Spatial and temporal differences in runoff DOC were significant ( $p<0.001$; ANOVA). Similar to the runoff, river DOC increased consistently over time (Fig. 2). Year-wise increase in river DOC was lowest at Adpr and highest at Rjds. On spatial scale, river DOC increased along the study gradient from Adpr (2007; 2.82-4.36 mg L ${ }^{-1}$ ) to Rjds (2007; 3.97-6.84 $\mathrm{mg} \mathrm{L}^{-1}$ ). This trend was common throughout the study period. Concentration of river DOC was lowest in low flow (summer) and highest in high flow (rainy season) (Fig. 3). Unlike AD-OC, the river DOC 

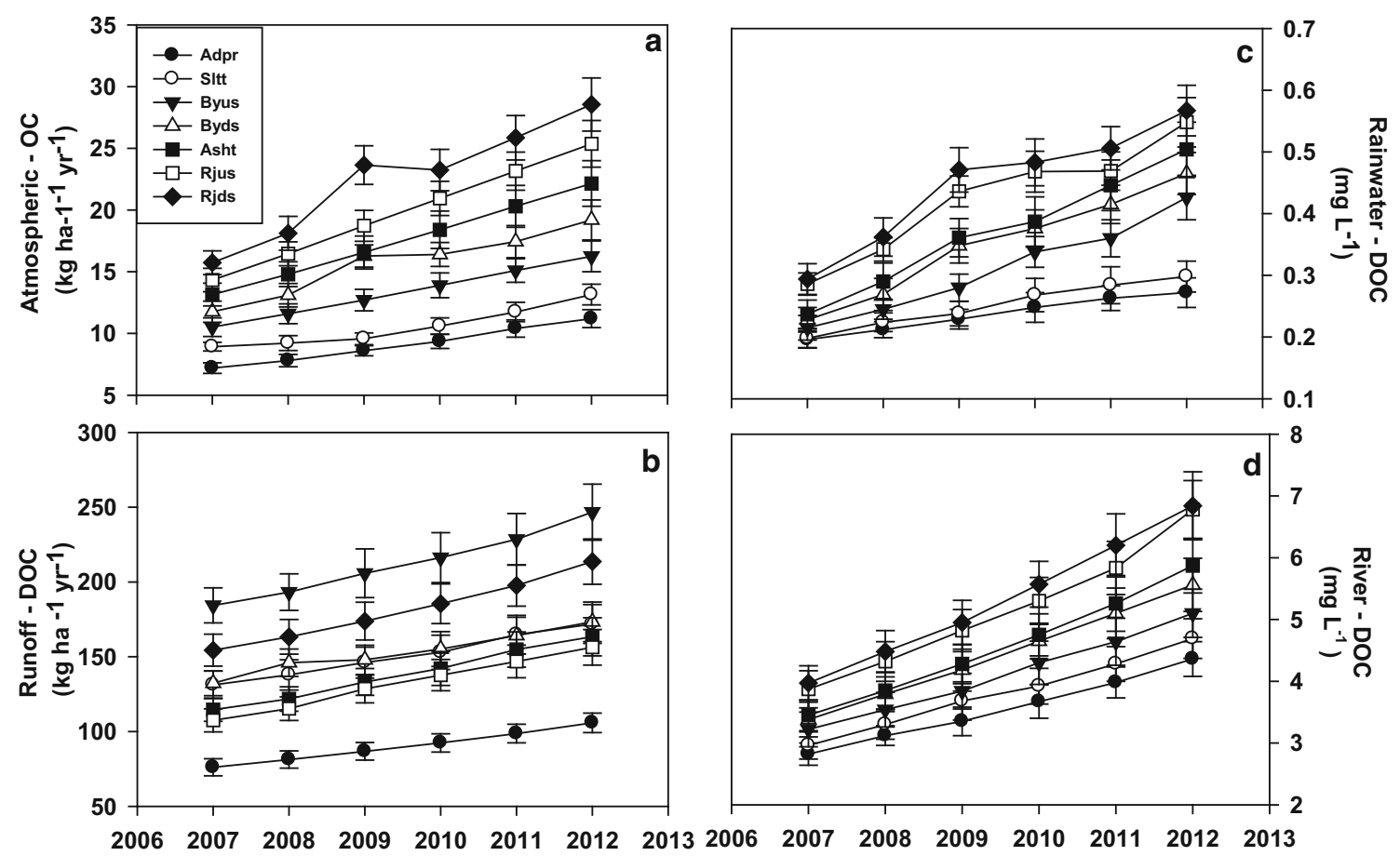

Fig. 2 Year-wise trends in a atmospheric deposition of organic carbon, $\mathbf{b}$ runoff DOC, $\mathbf{c}$ rainwater DOC; and $\mathbf{d}$ river DOC at seven study sites. Values are mean $\pm 1 \mathrm{SE}$. For atmospheric deposition and river DOC $n=36$, for runoff $n=12$
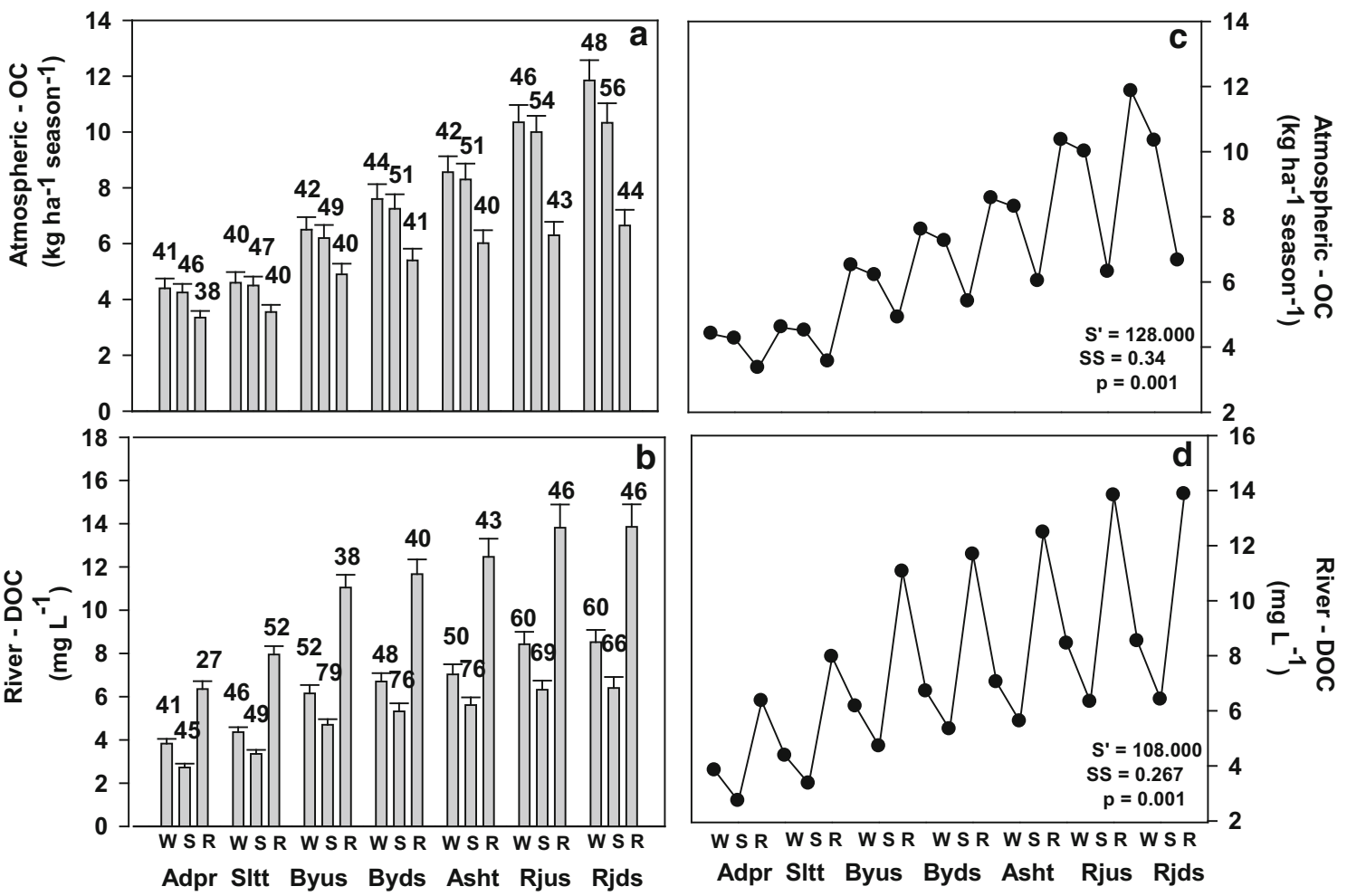

Fig. 3 Seasonal trends in a atmospheric deposition of organic carbon and, b river DOC and, Mann-Kendall test with Sen's slope statistics for $\mathbf{c}$ atmospheric OC, and $\mathbf{d}$ river DOC at seven study sites. Seasonal trend and statistics is based on final study year data and the numbers above bars $\mathbf{a}, \mathbf{b}$ represent percent difference with initial study year records. Values are mean $(n=12) \pm 1 \mathrm{SE}$. $S$ ' Sen's estimate, SS Sen's slope 

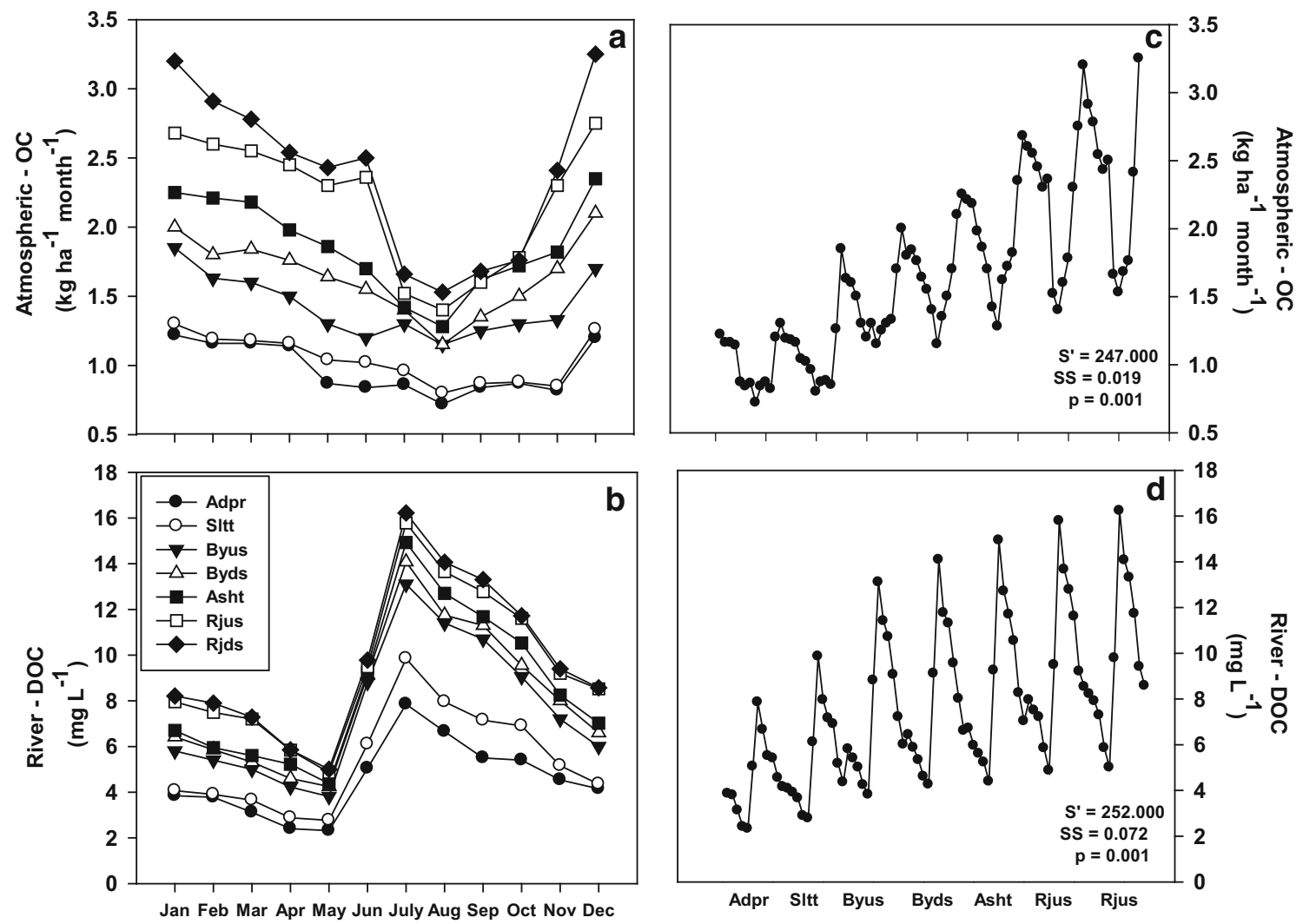

Fig. 4 Month-wise $(n=3)$ trends and time series analysis of atmospheric OC $(\mathbf{a}, \mathbf{c})$ and river DOC $(\mathbf{b}$, d). Time series statistics $(\mathbf{c}, \mathbf{d})$ is based on final study year data representing seven localities and 12 months. $S$ ' Sen's estimate; SS Sen's slope

concentration was highest in July irrespective of site (Fig. 4). The runoff DOC and river DOC showed significant $(p<0.001)$ positive correlation with AD-OC (Fig. 6). Similarly, runoff DOC showed significant $(p<0.001)$ positive correlation with $\mathrm{AD}-\mathrm{OC}$ and soil microbial activity (Fig. 6). Principal component analysis (PCA) showed two PCs accounting $88 \%$ of total variance with PC1 for $71 \%$ and PC2 for another $17 \%$ of total variance. The PCA clustering segregated seven sampling sites into four groups of similar characteristics (Fig. 7).

\section{Discussion}

An important problem likely to be continued to constrain water resource management in India is a consistently rising trend in atmospheric deposition of pollutants. Atmospheric particulates travel long distances from emission sources and reach waterways via direct deposition on water surface and via land deposition and subsequent runoff (Pandey et al. 2013, 2014b). Role of such inputs becomes important in areas characterized by rapid land use change and unprecedented increase in atmospheric deposition (AD). One of the objectives of the present study was to assess the extent to which atmospheric fluxes of OC are influenced by urban sources and how they vary with regional climate conditions. We present data on site-wise variations in atmospheric fluxes of OC to explain the influence of urban sources; inter-annual variations to explain rising trends over time and; seasonal (intra-annual) variations and month-wise trends to explain within a year influence of climatic variables (temperature, rainfall, wind etc.). We found significant seasonality and a consistently rising trend in AD-OC overtime as well as along the study gradient. Despite site-wise variations, a steadiness of the trend over time indicates strong local control connected with local changes in human activities. From about a decade, the region is witnessing a massive rise in population coupled urban development. Urban-industrial activities intensify as one travels from Site 1 to Site 7. In addition, the city side of the river receives emission 


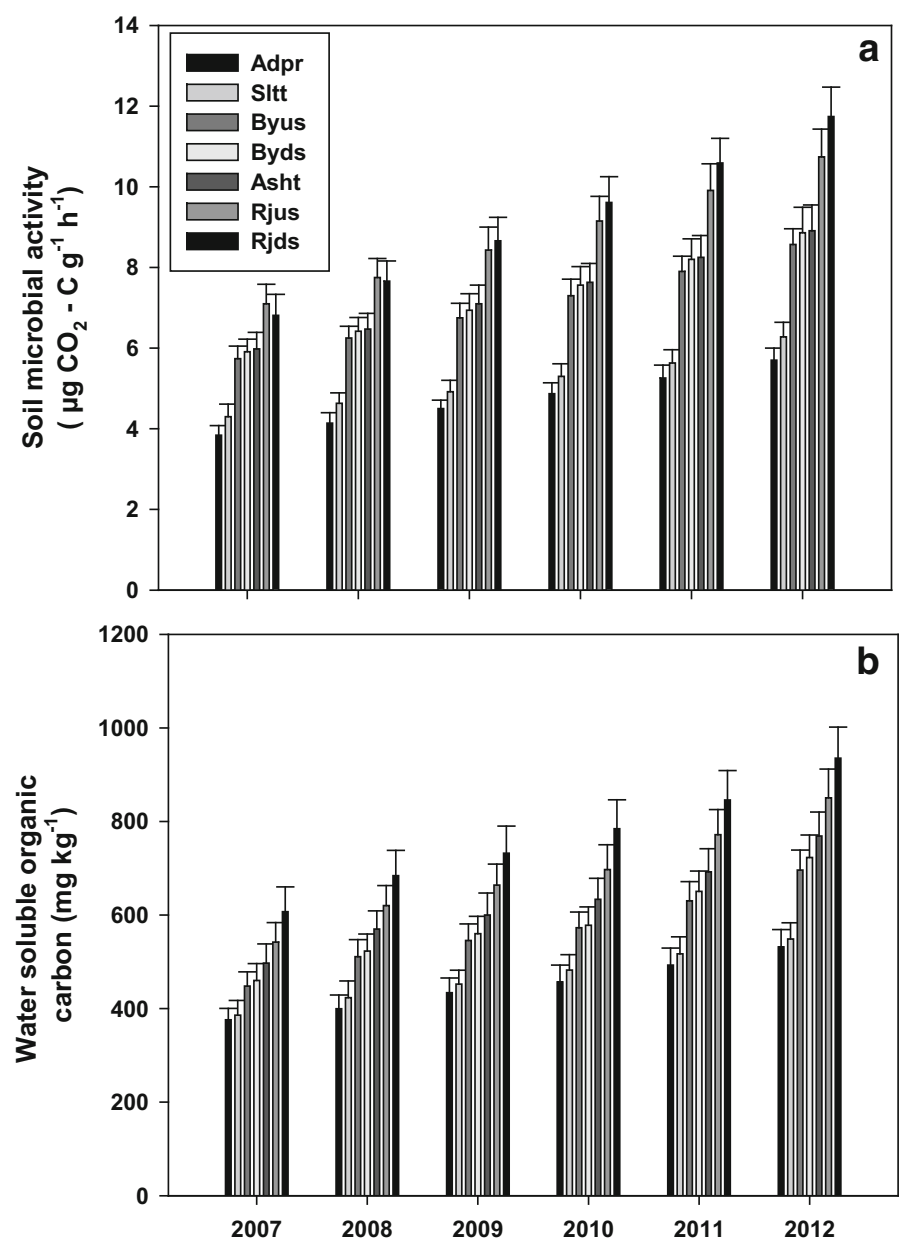

Fig. 5 Microbial activity (measured as substrate-induced respiration, SIR, a) and water soluble organic carbon (WSOC, b) in top $10 \mathrm{~cm}$ soil at different study sites. Values are mean $(n=36) \pm 1 \mathrm{SE}$

from burning of over 36,000 dead bodies with over 25,000 tons of dry wood for cremation annually. Thus, additional supply of carbon from biomass burning, which is continuously rising, could enhance AD-OC at downstream sites. Biomass burning has been identified as an important source of atmospheric OC in many parts of the world (Taylor 2010; Murillo et al. 2013). The AD-OC flux measured in the present study was in the range reported for north temperate Lake district (Buffam et al. 2011) and Atlantic Ocean (Jurado et al. 2004) but was higher than those reported for an arid metropolitan area of Phoenix, Central Arizona, USA (Lohse et al. 2008).

Urbanization is increasing rapidly in developing countries and is predicted to sizably enhance the atmospheric deposition of pollutant aerosols to cities and down-wind (Pandey et al. 2013). Lovett et al. (2000) suggested that urban atmosphere acts as a scrubber removing aerosols and vapors with dust and depositing them in and around the cities. For this reason, atmospheric deposition generally declines with distance from the city. The scrubbing effects of urban atmosphere may be further enhanced by the large mass of water along the city as the case of Ganga River in the present study. Further, the insoluble mineral particles act as cloud condensation nuclei and consequently enhance the overall deposition (Yin et al. 2002). In the present study, the AD-OC increased with proximity to urban core. Further, the particulate emission derived from site-specific activities (cooking, abraded streets, vehicle frequency, building construction, excavation and nearby agricultural lands), which are continuously rising due to population coupled urban development, may generate strong local control. The Mann-Kendall test and the Sen's slope estimates showed significant seasonality with increasing $\mathrm{AD}-\mathrm{OC}$ over the year. The variances in the residuals were almost constant. Intra-annual trends in AD-OC indicated long-range transport during summer, offsite scavenging during monsoon and enhanced 

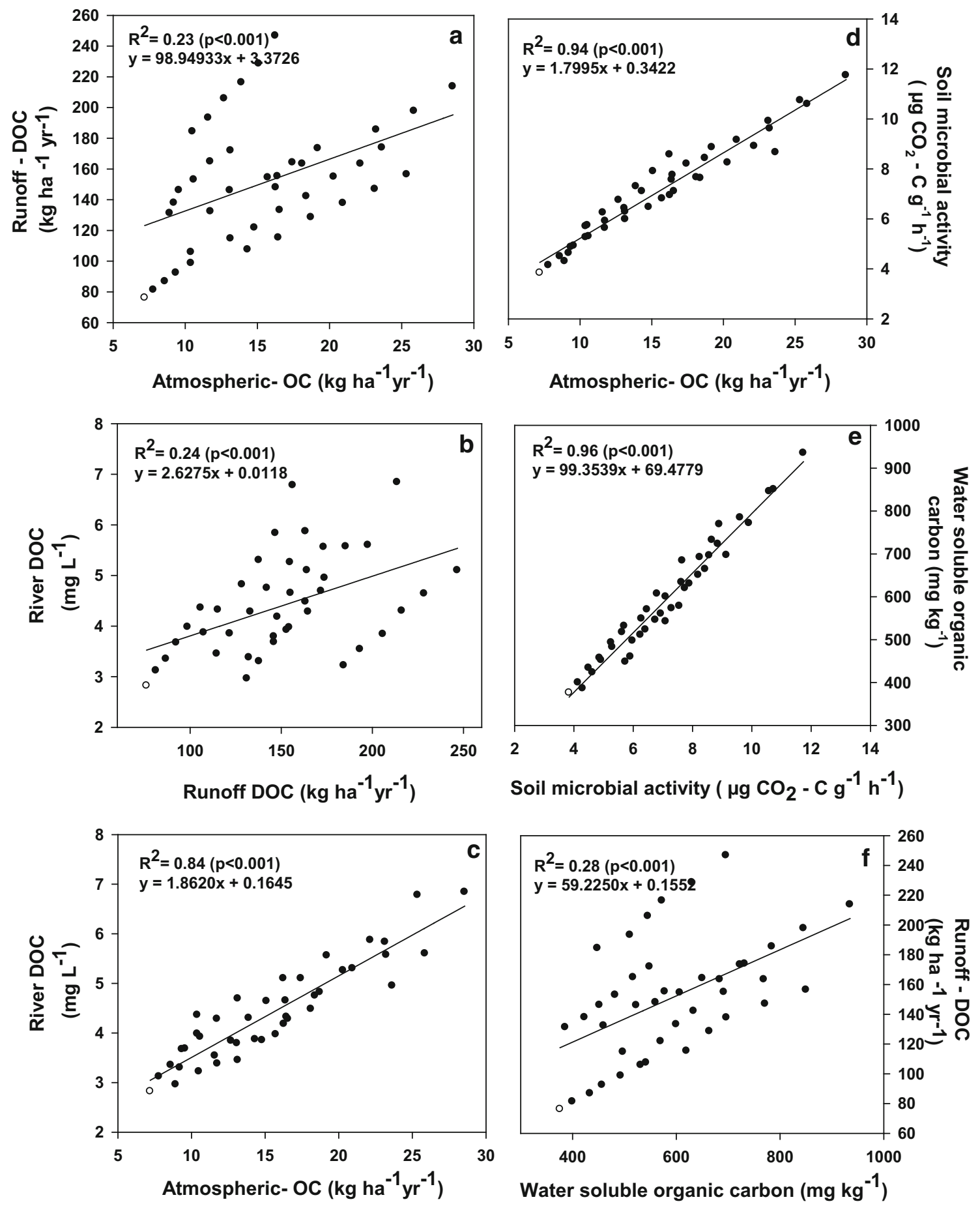

Fig. 6 Significant relationship between a atmospheric OC and runoff DOC, $\mathbf{b}$ runoff DOC and river DOC, $\mathbf{c}$ atmospheric OC and river DOC, $\mathbf{d}$ atmospheric OC and soil microbial activity, $\mathbf{e}$ soil microbial activity and water soluble organic carbon, and $\mathbf{f}$ water soluble organic carbon and runoff DOC

deposition rates during winter season (Lohse et al. 2008). As reported elsewhere (Lohse et al. 2008; Murillo et al. 2013), OC deposition showed the influence of urban emission and scrubbing effect and peaked in winter likely because of source effects coupled with low temperature, calm wind, low mixing heights and concurrent formation of inversion layer in winter season. 


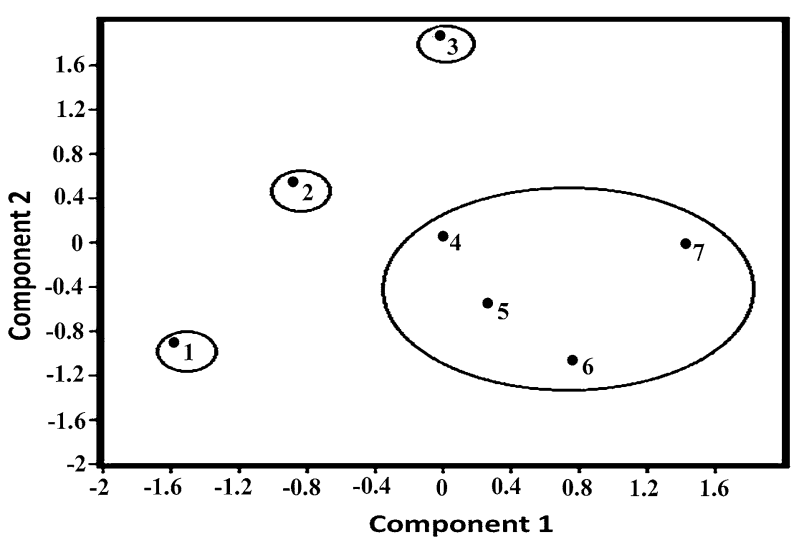

Fig. 7 Principal component analysis (PCA) showing the grouping of seven sampling sites into four clusters of similar characteristics

The observed trend in runoff DOC could be the result of a coupled effect of atmospheric deposition and local land use. Correlation analyses showed that the runoff DOC responded positively to AD-OC. Further, land use and hydrology are linked with each other in a complex way at multiple spatial and temporal scales (Matheussen et al. 2000). Hydrological release of carbon from land depends on geologic parent materials, topography, biota, land use, changes in soil chemistry and, microbial consumption or release of OC (Pandey and Pandey 2009). Site-wise differences in runoff DOC indicate such possible effects as the values were lowest for cemented terrains and highest for sites witnessing agricultural activity followed by woodland. The DOC of terrestrial origin is sensitive to watershed properties including organic matter quality and microbial activity in the catchment (Kalbitz et al. 2000; Tranvik and Jansson 2002; Kalbitz et al. 2007; Porcal et al. 2009). Previous studies (summarized by Gilvear et al. 2002) have shown strong links between hydrology and ecological quality of river ecosystems. Hydrological factors may influence DOC production and transport through a number of ways (Evans et al. 2005, 2006). In the present study, a corresponding trend in surface runoff DOC and river DOC indicates the role of hydrological factors influencing DOC production and export. Hydrological drivers coupled with strong local controls could explain a monotonic rise in DOC observed in this study. Evans et al. (2006), while evaluating the climate change hypothesis and alternative drivers of rising DOC export from organic soils, argued that if hydrology is the principal driver of increased freshwater DOC, a concurrent monotonic trend would be expected.

In a study combining in vitro manipulation with mesocosm and field experiments, Fenner and Freeman (2011) observed that dry periods stimulate bacterial growth and enzymatic degradation of organic matter in peat lands and subsequent re-wetting enhances carbon losses to receiving waters. In the region representing this study, although extreme weather events are not common, seasonal cycle of temperature and precipitation could similarly influence organic matter and microbial activity in the sub-catchment. Possibly for this reason, river DOC was highest in July indicating the first flush effect. We found enhanced microbial activity and a corresponding rise in water soluble organic matter (WSOC) in response to atmospheric AD-OC input over time along the study gradient. As observed in present study, increased microbial activity in soil enhances the production of dissolved organic carbon (Kalbitz et al. 2000, 2007). It seemed that the consistently rising runoff DOC observed in this study has an important link to microbial processing of organic matter in dry seasons followed by pulsed response and subsequent lateral flow in rainy season (Fenner and Freeman 2011; Ritson et al. 2014). Elevated inputs of OC may further enhance microbial activity and pulsed responses to rainfall (Sponseller 2007). Although long-term studies are required to confirm this issue, our data clearly indicate increasing AD-OC linked soil stimulation as a possible mechanism addressing causative relationship of rising DOC in land surface runoff. This highlights a need for additional research into AD driven changes in catchment processes considering other factors potentially operating at smaller scales especially in the IndoGangetic plains.

The solute chemistry of a river depends on constituents added through surface discharge as well as through atmospheric deposition, and data on these issues are important to uncover cross-domain carbon linkages and to 
design action plan for integrated river basin management (IRBM). Our data indicate a highly dynamic and tightly coupled linkage between AD inputs, runoff chemistry and river water chemistry. The common mechanisms used to explain increases in freshwater DOC include climate change (Freeman et al. 2001), elevated $\mathrm{CO}_{2}$ (Freeman et al. 2004), hydrologic factors (Evans et al. 2005), changing atmospheric deposition chemistry (Monteith et al. 2007; Pandey and Pandey 2013), enhanced pelagic production (Kirchman et al. 1991) and declining sulfate deposition (Evans et al. 2006). In the present study, variation in river DOC could be the result of a combined influence of $\mathrm{AD}$ inputs, hydrological point discharge, non-point discharge and sewage inputs. We found a positive relationship $\left(R^{2}=0.24 ; p<0.001\right)$ between runoff DOC and river DOC indicating that hydrological flushing is an important vector of river DOC. Seasonal variability in river DOC could be linked to catchment flushing as river DOC increased significantly in monsoon high flows. In dry seasons, when surface runoff remains at minimum, changes in mid-stream DOC may be attributed to AD-OC, pelagic production and sewage input. Earlier studies have shown positive relationships between discharge and DOC concentration in river systems (Westhorpe and Mitrovic 2012). Large rain event often contributes a large proportion of total flow and accounts for a significant proportion of total DOC exported from a catchment (Buffam et al. 2001). In this study, DOC concentration during low discharge periods were fairly low and increased substantially during high discharge events ranging from 11.7 to $16.2 \mathrm{mg} \mathrm{L}^{-1}$. Significant positive relationship $\left(R^{2}=0.59, p<0.001\right)$ was found between DOC concentrations and river discharge indicating that during period of high discharge allochthonous sources dominate. Discharge appeared highest in August while river DOC peaked in July indicating first flush effect. The overall results of annual trend, however, suggest the role of a mixture of terrestrial, atmospheric and aquatic sources (allochthonous and phytoplankton derived $\mathrm{C}$ pool together with $\mathrm{AD}-\mathrm{OC}$ and anthropogenic point sources discharge). Correlative evidence showed that the DOC in runoff $\left(R^{2}=0.23 ; p<0.001\right)$ and in river $\left(R^{2}=0.84 ; p<0.001\right)$ was positively related to AD-OC. The relationships of runoff DOC with AD-OC, river DOC and WSOC (Fig. 6a, b, f) appeared weak and showed quite linear dependence of several groups reflecting site-specific inter-annual variations. Large variances associated with the main line of best fit representing entire data for inter-annual and between-site variations are due probably to site characteristics such as vegetation, soil, land use etc. and associated variations, in addition to AD-OC, resulting in linear dependence of several groups and low value of $\mathrm{R}^{2}$. These relatively independent groups explaining 58-76\% variances have relevance identifying sitespecific effect of runoff. Principal component analysis (PCA) of entire data set identified four distinct groups of sampling locations. Group 1 showed negative relationship with both the PCs reflecting the role of natural controls at Site 1 (Adpr). The deviation of Site 2 and 3 (upstream to urban core) from rest of the sites indicated a combined influence of $\mathrm{AD}$ and runoff inputs. The fourth group clustered rest of the sites indicating the influence of $\mathrm{AD}$, sewage and runoff inputs at downstream sites.

For evaluating the effect of changing state of atmosphere-land-water transfer, we tested whether river DOC was positively related to AD-OC and runoff DOC and whether the microbial activity and WSOC were positively related to AD-OC. The river DOC showed characteristic synchrony with AD-OC and runoff DOC and the latter showed strong synchrony with microbial activity and WSOC. We used C:N ratio as an indicator of terrestrial $\mathrm{C}$ input. Emeis et al. (2000) argued a $\mathrm{C}: \mathrm{N}$ ratio $>10$ indicates high proportion of terrestrial organic matter. Meyers (2003) referred C:N > 20 to terrestrial origin. In the present study, despite a declining trend over time, the C:N ratios were invariably high $(>22)$ indicating terrestrial influence (Elser et al. 2000). It seems that if the rising trend of atmospheric inputs is continuing, as expected for countries like India, it would enhance the runoff $\mathrm{C}$ transport and, in turn, the DOC in surface waters. Data on these issues are important in understanding the ongoing changes in the biogeochemical cycle of carbon and options for managing carbon cycle for mitigating future climate change. Our study showed that the hydrological transport of carbon as influenced by land use and AD-OC is an important vector of DOC to Ganga River in Varanasi region. Since the Ganges is an oceanic river, atmospheric and terrestrial carbon subsidies bear a particular significance.

\section{Conclusions}

This study showed that the Varanasi region is receiving increasingly high input of organic carbon (OC) through atmospheric deposition (AD). Changing land use pattern coupled with rising input of AD-OC may alter the atmosphere-land-water transfer causing a shift in carbon balance in the river. Regional carbon fluxes 
and pools, therefore, would be misrepresented without appropriately considering the changing state of transecosystem linkages. Thus, the models that incorporate carbon data based only on soil $\mathrm{C}$ pool, vegetation $\mathrm{C}$ pool and vegetation-atmospheric-C fluxes may over- or underestimate the future carbon budget. Our study, that forms the first report on atmosphere-land-water-C linkages in Ganga River and identifies region-specific landscape elements which are more vulnerable to AD inputs and runoff $\mathrm{C}$ transfer, suggests the need for largescale inter-regional time series data on carbon balance as influenced by land use change and increasing ADOC inputs. Long-term data on these issues would help predicting future state of climate change drivers and have relevance from climate change perspective and for designing action plan for integrated river basin management.

Acknowledgements We thank Coordinator, Centre of Advanced Study in Botany, Banaras Hindu University for laboratory facilities. We are grateful to reviewers for their critical and helpful comments. The work was supported by the University Grant Commission, New Delhi (Grant No. 32-383/2006 SR and as fellowship to PK), National Academy of Sciences, India (as fellowship to AVS) and Banaras Hindu University (as fellowship to RS).

Open Access This article is distributed under the terms of the Creative Commons Attribution 4.0 International License (http:// creativecommons.org/licenses/by/4.0/), which permits unrestricted use, distribution, and reproduction in any medium, provided you give appropriate credit to the original author(s) and the source, provide a link to the Creative Commons license, and indicate if changes were made.

\section{References}

Aber J, McDowell W, Nadelhoffer K, Magill A, Berntson G, Kamakea M, McNulty S, Currie W, Rustad L, Fernandez I (1998) Nitrogen saturation in temperate forest ecosystems. Hypothesis revisited. BioScience 48:921-934

American Public Health Association (1998) Standard methods for the examination of water and wastewater. APHA, Washington, DC

Anderson JPE, Domsch KH (1978) A physiologically active method for the quantitative measurement of microbial biomass in soils. Soil Biol Biochem 10:215-221

Buffam I, Galloway JN, Blum LK, McGlathery KJ (2001) A stormflow/baseflow comparison of dissolved organic matter concentrations and bioavailability in an Appalachian stream. Biogeochemistry 53:269-306

Buffam I, Turner MG, Desai AR, Hanson PC, Rusak JA, Lottig NR, Stanley EH, Carpenter SR (2011) Integrating aquatic and terrestrial components to construct a complete carbon budget for a north temperate lake district. Glob Change Biol 17:1193-1211

Ciavatta C, Govil M, Antisari VL, Sequi P (1991) Determination of organic carbon in aqueous extract of soil and fertilizers. Commun Soil Sci Plant Anal 22:795-807

Cole J, Prairie Y, Caraco N, McDowell W, Tranvik L, Striegl R, Duarte C, Kortelainen P, Downing J, Middelburg J, Melack J (2007) Plumbing the global carbon cycle: integrating inland waters into the terrestrial carbon budget. Ecosystems 10:171-184

Dadhwal VK (2012) Assessment of Indian carbon cycle components using earth observation systems and ground inventory. Int Arch Photogram Remote Sens Spat Inform Sci 39:249-254

Elser JJ, Fagan WF, Denno RF, Dobberfuhl DR, Folarin A, Huberty A, Interlandi S, Kilham SS, McCauley E, Schulz KL, Siemann EH, Sterner RW (2000) Nutritional constraints in terrestrial and freshwater food webs. Nature 408:578-580

Emeis KC, Struck U, Leipe T, Pollehne F, Kunzendorf H, Christiansen C (2000) Changes in the C, N, P burial rates in some sediments over the last 150 years: relevance to $P$ regeneration rates and the phosphorus cycle. Marine Geol 167:43-59

Evans CD, Monteith DT, Cooper DM (2005) Long-term increases in surface water dissolved organic carbon observations, possible causes and environmental impacts. Environ Pollut 137:55-71

Evans CD, Chapman PJ, Clark JM, Monteith DT, Cresser MS (2006) Alternative explanations for rising dissolved organic carbon export from organic soils. Glob Change Biol 12(11):2044-2053

Fenner N, Freeman C (2011) Drought-induced carbon in peatlands. Nat Geosci 4:895-900

Freeman C, Evans CD, Monteith DT, Reynolds B, Fenner N (2001) Export of organic carbon from peat soils. Nature 412:785

Freeman C, Fenner N, Ostle NJ, Kang H, Dowrick DJ, Reynolds B, Lock MA, Sleep D, Hughes S, Hudson J (2004) Export of dissolved organic carbon from peat lands under elevated carbon dioxide levels. Nature 430:195-198

Gillet RW, Ayers GP (1991) The use of thymol as a biocide in rain water samples. Atmos Environ 25A:2677-2681

Gilvear DJ, Heal KV, Stephen A (2002) Hydrology and ecological quality of Scottish river ecosystems. Sci Total Environ 294:131-159

Jurado E, Jaward FM, Lohmann R, Jones KC, Simó R, Dachs J (2004) Atmospheric dry deposition of persistent organic pollutants to the Atlantic and inferences for the global oceans. Environ Sci Technol 38:5505-5513

Jurado E, Dachs J, Duarte CM, Simó R (2008) Atmospheric deposition of organic and black carbon to the global oceans. Atmos Environ 42:7931-7939

Kalbitz K, St Solinger, Park J-H, Michalzik B, Matzner E (2000) Controls on the dynamics of dissolved organic matter in soils: a review. Soil Sci 165:277-304 
Kalbitz K, Meyer A, Yang R, Gerstberger P (2007) Response of dissolved organic matter in the forest floor to long-term manipulation of litter and throughfall inputs. Biogeochemistry 86:301-318

Kirchman DL, Suzuki Y, Garside C, Ducklow HW (1991) High turnover rates of dissolved organic carbon during a spring phytoplankton bloom. Nature 352:612-614

Kopácèk J, Cosby BJ, Evans CD, Hruška J, Moldan F, Oulehle F, Šantrůčková H, Tahovská K, Wright RF (2013) Nitrogen, organic carbon and sulphur cycling in terrestrial ecosystems: linking nitrogen saturation to carbon limitation in soil microbial processes. Biogeochemistry 115:33-51

Langley JA, Megonigal JP (2010) Ecosystem response to elevated $\mathrm{CO}_{2}$ levels limited by nitrogen- induced plant species shift. Nature 466:96-99

Lohse KA, Hope D, Sponseller R, Allen JO, Grimm NB (2008) Atmospheric deposition of carbon and nutrients across an arid metropolitan area. Sci Total Environ 402:95-105

Lovett GM, Traynor MM, Pouyat RV, Carreiro MM, Zhu WX, Baxter JW (2000) Atmospheric deposition to oak forests along an urban-rural gradient. Environ Sci Technol 34:4294-4300

Maiti SK (2001) Handbook of methods in environmental studies. In: Water and wastewater, vol 1. ABD Publisher, Jaipur

Matheussen B, Kirschbaum RL, Goodman IA, O'Donnell GM, Lettenmaier DP (2000) Effects of land cover change on stream flow in interior Columbia River Basin (USA and Canada). Hydrol Proc 14:867-885

Meyers PA (2003) Applications of organic geochemistry to paleolimnological reconstruction: a summary of examples from the Laurentian Great Lakes. Org Geochem 34:261-289

Michel P (1984) Ecological methods for field and laboratory investigation. Tata McGraw-Hill Publ Comp, New Delhi

Monteith DT, Stoddard JL, Evans CD, deWit HA, Forsius M, Høgasen T, Wilander A, Skjelkvale BL, Jeffries DS, Vuorenmaa J, Keller B, Kopacek J, Vesely J (2007) Dissolved organic carbon trends resulting from changes in atmospheric deposition chemistry. Nature 450:537-540

Murillo JH, Marin JFR, Roman SR, Guerrero VHB, Arias DS, Ramos AC, Gonzalez BC, Baumgardner DG (2013) Temporal and spatial variations in organic and elemental carbon concentrations in PM10/PM2.5 in the metropolitan area of Costa Rica, Central America. Atmos Pollut Res 4:53-63

Pandey J (2011) The influence of atmospheric deposition of pollutant elements on cross-domain causal relationships at three tropical freshwater lakes of India. Lakes Reser Res Manag 16:111-119

Pandey J, Pandey U (2009) Microbial processes at land water interface and cross-domain causal relationships as influenced by atmospheric deposition of pollutants in three freshwater lakes in India. Lakes Reser Res Manag 14:71-84

Pandey U, Pandey J (2013) Impact of DOC trends resulting from changing climatic extremes and atmospheric deposition chemistry on periphyton community of a freshwater tropical lake of India. Biogeochemistry 112:537-553

Pandey J, Singh AV, Singh A, Singh R (2013) Impacts of changing atmospheric deposition chemistry on nitrogen and phosphorus loading to Ganga River (India). Bull Environ Contam Toxicol 91:184-190

Pandey J, Pandey U, Singh AV (2014a) The skewed N:P stoichiometry resulting from changing atmospheric deposition chemistry drives the pattern of ecological nutrient limitation in Ganges River. Cur Sci 107(06):956-958

Pandey J, Pandey U, Singh AV (2014b) Impact of changing atmospheric deposition chemistry on carbon and nutrient loading to Ganga River: integrating land-atmosphere-water components to uncover cross-domain carbon linkages. Biogeochemistry 119:179-198

Perakis SS, Hedin LO (2002) Nitrogen loss from unpolluted South American forests mainly via dissolved organic compound. Nature 145:416-419

Porcal P, Koprivnjak JF, Molot LA, Dillon PJ (2009) Humic substances-part 7: the biogeochemistry of dissolved organic carbon and its interactions with climate change. Environ Sci Pollut Res 16:714-726

Ramanathan V, Garmichael G (2008) Global and regional climate change due to black carbon. Nature Geosci 1:221-227

Reich PB, Hobbie SE, Lee T, Ellsworth DS, West JB, Tilman D, Knops JNH, Naeem J, Trost J (2006) Nitrogen limitation constrains sustainability of ecosystem response to $\mathrm{CO}_{2}$. Nature 440:922-925

Ritson JP, Graham NJD, Templeton MR, Clark JM, Gough R, Freeman C (2014) The impact of climate change on the treatability of dissolved organic matter (DOM) in upland water supplies: a UK perspective. Sci Total Environ 473-474:714-730

Sponseller RA (2007) Precipitation pulses and soil $\mathrm{CO}_{2}$ flux in a Sonoran Desert Ecosystem. Glob Change Biol 13:426-436

Taylor D (2010) Biomass burning, humans and climate change in southeast Asia. Biodiv Cons 19:1025-1042

Tranvik LJ, Jansson M (2002) Climate change: terrestrial export of organic carbon. Nature 415:861-862

Voghel AI (1971) A text book of quantitative inorganic analysis, 4th edn. The english language book society, Longman

Westhorpe DP, Mitrovic SM (2012) Dissolved organic carbon mobilisation in relation to variable discharges and environmental flows in a highly regulated lowland river. Mar Freshwater Res 63:1218-1230

Willey JD, Kieber RJ, Eyman MS, Avery GB Jr (2000) Rainwater dissolved organic carbon: concentrations and global flux. Glob Biogeochem Cycle 14:139-148

Yin Y, Wurzler S, Levin Z, Reisin TG (2002) Interactions of mineral dust particles and clouds: effects on precipitation and cloud optical properties. J Geophys Res 107:AAC 19-1-AAC 19-14 